\title{
CURRICULUM DEVELOPMENT OF MULTICULTURAL- BASED ISLAMIC EDUCATION AS AN EFFORT TO WEAVER RELIGIOUS MODERATION VALUES IN INDONESIA
}

\author{
Achmad Anwar Abidin \\ anwarabidin@staidagresik.ac.id \\ STAI Daruttaqwa Gresik \\ Muhammad Ali Murtadlo \\ alimurtadlo@,iainponorogo.ac.id \\ IAIN Ponorogo
}

\begin{abstract}
: the discussion in this article refers to the development of a multicultural-based Islamic religious education curriculum as an effort to develop the values of religious moderation in Indonesia that have been implemented. The research method in this article is an observative research on educational institutions in Indonesia from the policy side of government and related educational institutions. The conclusion is as follows: 1). Multicultural-based Islamic religious education learning Model. In developing a multicultural learning model that must be blessed is a truly multicultural-laden learning activity. Learning activities are designed to provide a learning experience involving mental and physical processes through interaction between learners, learners with teachers, the environment, and other learning resources in order to achieve basic competencies. 2). Learning Media of Islamic religious education. Media can also be called tools while commonly used at this time is an audio visual aids, which means audiovisual aids are materials or tools used in the situation to help the writings and words spoken in the transmission of knowledge, attitudes, and ideas in the development of Islamic education be bases multicultural. 3). Sources of educational learning Islamic religion-based multicultural sources of Islamic values as a cornerstone of Islamic education The Foundation consists of the Qur'an and Sunnah Prophet Muhammad
\end{abstract}


IJIERM: Vol. 2 No. 1 Januari - April 2020

SAW that was developed with Ijtihad, Al Maslahah al murincorrectly, Istihsan, Qiyas and so on and from the source of learning it in the Islamic Religious education based multicultural developed with regard to the values of Islam Rahmatan li Al-"alamin that put forward the principles of Islamic Humanist, tolerant, democratic, and accommodating local cultures.

Keywords; Curriculum Development, Multicultural-Based Islamic Education

\section{INTRODUCTION}

Education is a fundamental factor in the effort to improve the level of living in addition to better social economic development. Education was also seen as a strategy to boost the nation's reputation. With the crucial role of education, governments pay more attention to all aspects of education in the hopes that it can become the spearhead of Indonesia's development. It is evidenced in the form of legal guarantees, increased education budgets and other rules to improve the quality of national education.

These efforts are part of the realization of the mandate of the Constitution 1945 which is a reflection of our founding fathers. Paragraph 2 of article 31 confirms that every citizen is entitled to the teaching and the Government must provide his budget. Paragraph 3 of the same article confirms that the Government is drafting a national education system that emphasizes the aspects of faith and piety in the framework of the intellectual enlightenment of the nation governed by law.

Regarding multicultural education, Mahfud defines it as the process of planting a living way of respecting, sincere, and tolerant of cultural diversity that lives in the midst of the plural society. With multicultural education, it is hoped that the people's mental flexibility and agility face a conflict of social conflicts, so that the unity of nations is not easily broken and cracked. ${ }^{1}$

The Oregon Department of Education defines multicultural education as a lifelong learning process designed to empower all students to be knowledgeable, caring, and active to participate in their communities. This education is inclusive

\footnotetext{
${ }^{1}$ Chairul Mahfud, Pendidikan Multikultural (Yogyakarta: Pustaka Pelajar, 2007), p. 67.
} 
and respects all ethnic, racial and cultural backgrounds including respecting staff, families, students and the community. ${ }^{2}$

Of these two understandings it can be concluded that the essence of multicultural education is how to teach and embed students the value and attitude of tolerance, the way of respect, and to participate in a diverse community of ethnicity, race, cultural and religious background, as well as the social strata of others.

In the context of Indonesia, since the implementation of regional autonomy began in 2001, provincial and district governments are also responsible for the development of education as one of the strategic policies. This is in line with a reform message that gradually provides more free-space motion in the context of autonomy. No exception in education, it indicates a decentralized in education management. ${ }^{3}$

However, the negative impact of regional autonomy policy is the presence of local egocentrism, in the form of dislikes in people from outside the region. Many of these issues resulted in conflict as happened in Poso, Ambon, and Kalimantan. All of this occurs due to poverty, misunderstanding of ethnic, cultural and religious differences, as well as the influence of aggressive global culture and full of competition. ${ }^{4}$

In the theoretical context, the concept of multicultural education is sounding persuasive, but not necessarily effective in the level of the practice. The main difficulty in implementing multicultural education programs is the difference in objectives determined by each school. Nieto and Bode describe four types of programs whose objectives are wider, namely: (1) tolerance, which is to emphasize association with different people and reject the significance of the differences; (2) Acceptance, which is to acknowledge that differences are important and do not dispute diversity; (3) Respect, which is to look at differences in the positive context and encourage learning about diversity, and (4) affirmations, solidarity and criticism, which is to build issues of social justice

\footnotetext{
2 Oregon Department of Education, Multicultural Education - Definition, accesed by 19 Juni 2019, http://www.ode.state.or.us/search/page/?id=2575,

3 Dedi Supriadi, Reformasi Pendidikan dalam Konteks Otonomi Daerah (Yogyakarta: Adicita, 2000), p. 142.

4 Sutijono, Multicultural Education in Indonesia: An Alternative for National Education in Global Era, Journal Sosio Humanika: Jurnal Pendidikan Sains Sosial dan Komunikasi. Vol. 3, No. 1 2010, p. 55.
} 
IJIERM: Vol. 2 No. 1 Januari - April 2020

commitments outside the classroom, reject a engineered cultural outlook, and encourage understanding that the culture is dynamic and changing over time ${ }^{5}$

Regarding the objectives of multicultural-based education, Rus'an and Lisnawaty identified the following things: (1) to enable the role of the school to view the existence of diverse students; (2) To assist students in establishing positive treatment of cultural, racial, ethnic, religious groups; (3) Provide student resilience by teaching them to take their decisions and social skills; and (4) to assist learners in establishing cross-cultural dependence and giving them a positive picture of the group's differences. ${ }^{6}$

We know that during the period of 32 years the country was under the rule of the new Order. During this period, the nation has been buried and only introduced through the symbol without touching its essence. The political mono culturalism implemented by the new Order government in the name of stability for development has eliminated the local cultural genius. Whereas the system of social cultural traditions is a wealth but priceless.

Educational institutions as forming the characters of the nation get the challenge. How education can answer the needs of the community that dampen conflicts and build a peaceful living atmosphere between groups, tribes, races and religions. That is the basic question as our common evaluation. Heterogeneous community needs are about how to live peacefully and amicable. At this point the Community Empowerment Strategy in multicultural dynamics is necessary. His offer was a consciousness of multiculturalism raised through multicultural education in schools.

According to Jose A. Cardinas (1975) in Suparta Mundzier, explaining the importance of multicultural education is based on five considerations: First: Incompatibility, second: Other language acquisition, third: cultural pluralism, fourth: development of positive self-image, and fifth: equality of Education Opportunity (equality of educational opportunity), all of which are in fact.

On the other hand, Donna M. Gollnick (1983) mentions that the importance of multicultural education is in the background of several assumptions: first, every culture can interact with other cultures, and can even

\footnotetext{
5 Koppelman, "What Are the Goals ...", in Sonia Nieto dan Patty Bode. Affirming diversity: The sociopolitical context of multicultural education (Boston: Pearson, 2008), p. 426-427

${ }^{6}$ Rus'an dan Sri Dewi Lisnawaty, Urgensi Pendidikan Multikultural dalam Pendidikan Islam Di Madrasah Aliyah Negeri (MAN) Poso Pesisir, Istiqra, Vol. 1, No. 1 (2013): p. 97-98.
} 
contribute to each other; Second, social justice and equal opportunities for all people are the right for all citizens; Third, the distribution of the unwillingness can be shared jointly to all ethnic groups; the fourth, the education system provides critical functions to the needs of attit udes and values for the sake of democratic society; and fifth, teachers and educational practitioners can assume a leadership role in creating an environment that supports multicultural education.

Meanwhile, multicultural education is important because this concept at least rests on two beliefs. Firstly, socially all cultural groups can be representative and coexist together with others. Secondly, discrimination and racism can be reduced through the determination of the positive image of ethnic diversity and the knowledge of other cultures. Therefore, multicultural insights and ideas need to be confirmed in the educational world.

If multicultural education can be done in schools, the result will give birth to the civilization and the weaving of people who are tolerant, democratic, full of virtue, like help, tolerance, harmony, beauty and uphold the values of humanity. In essence, the idea and design of a school multicultural-based is a necessity with the record, that his presence is obscuring and or creating the uncertainty of the identity of the existing groups.

Preferably colleges, including universities of religious affiliation development models of multicultural education are conducted in an integrated way. The college curriculum needs to adopt and accommodate diversity of value in different cultural and religious-based communities. Universities can develop educational models according to the needs and conditions of each. With the development of that curriculum, the college is expected to be an agent of peace and nation advancement, no exception colleges of religious affiliation.

Multicultural education is also important to bridge differences in interests and character differences in local education. The difference in importance is one of the constraints of national education development over the last half century.

Multiculturalism in the context of respecting other cultures and religions is one of the practices of Islamic religious beliefs. In Islam is mentioned, we must also be paddling other religions and cultures as long as they do not interfere with existing order and system. However, the pluralism principle that the disparate religions of different religions is unacceptable, but religion is not the same as each other. 
IJIERM: Vol. 2 No. 1 Januari - April 2020

It becomes important to discuss the model of multicultural education as it is according to the culture of our country. The appropriate model of education will make it easier for every stakeholder to apply the multicultural education. In any discussion that has often implemented multicultural education can at least be contained in Islamic education and citizenship education, how to choose a model that corresponds to the characteristics of these two subjects.

Why this model of education is important? It is because the education model is a guideline for the design and implementation of education. Therefore, the selection of models is strongly influenced by the nature of the material to be taught, the objectives (competencies) that will be achieved in the learning, as well as the ability level of learners. A learning design or learning plan is called using a learning model when having 4 special features: 1) Rational logical theories compiled by its creators and developers. 2) The foundation of thinking about what and how students learn (the learning objective that will be accomplished. 3) The behaviour required for the model to be implemented successfully. 4) The learning environment needed for that learning objective can be achieved

Media is a further necessity for the implementation of the model because the media is the key to the subject of the students. If the media is not suitable then the subject of study materials will be difficult to do. The existence of this learning media is to facilitate the material to convey the students.

Then, the essence of every learning material learning should be derived from the right source of learning and erroneous learning resources, then the material is taught wrongly and resulted in a mistaken understanding. Therefore, the discussion of this time the author will discuss about the model, media and learning resources of the multicultural-based Islamic education as an effort to participate in developing Islamic religious education that Rabmatan Lil'alamiin (mercy to all universe).

\section{METHODS}

This research is a qualitative study focusing on the observation of the policy and its implementation through library research, where the author uses a descriptive research method with more emphasis on the power of data analysis on the sources obtained from books and other scientific writings by relying on the theories that exist to be interpreted widely and in depth. To that end, the author uses a descriptive library approach by using the books of the multicultural 
education concepts, namely the policy in Indonesia and its implementation to the existing education institutions.

Additionally the authors also use a text study that includes. First, the literature study as a theoretical examination of a discipline that needs to be continued through empirical exams. Secondly, the study of texts seeking to study linguistic theories, the study of linguistics or the study of language development or called by sociolinguistic or psycolinguistic. Thirdly, a literature study that all of its substantiates required a philosophical or theoretical processing of its values. Fourth, is a literature study of literary works. Based on the opinion, the author in taking the study of the literature as a theoretical examination of a discipline.

To analyze the data, the authors use the Content Analysis method as a research technique, this analysis includes special procedures that are according to experts in the form of objectivity, systematic approach and generalization. It serves to scientifically process data, as well as research techniques. It aims to provide knowledge, open new insight and practical guidance on implementation.

To facilitate the writing, the authors use several discussion methods, among others: deduction, induction and comparison. The deduction method is a flow of discussion that departs from a general reality to a specific discussion, the deduction method is a method that departs from general knowledge to a specific occurrence. This method is used to describe the data of a common opinion that is then outlined into specific things. The induction method is also a flow that departs from special reality or concrete events, and then from the concrete reality is drawn in general that is general. This method is used to take an outline of things that are particularly common to the multicultural education policies in Indonesia. Authors also use the authors method of comparison to draw conclusions by comparing ideas, opinions and understandings to know the equation of various ideas and also to know the difference with other ideas, then can be drawn a new conclusion.

\section{LEARNING MODELS OF ISLAMIC RELIGIOUS EDUCATION IN MULTICULTURAL-BASED}

\section{Multicultural-handed models}

As a heterogeneous nation or compound, multiculturalism is very important to develop then multicultural programs are always aimed at fostering understanding and participation from community groups in order to grow 
IJIERM: Vol. 2 No. 1 Januari - April 2020

sympathies against the multicultural struggle. The steps that need to be done are as follows: 1). Multiculturalism needs to be part of education curriculum. The multicultural dimension should be reflected in the lessons of citizenship, geography, literature, history, politics and economics. Religious and moral education needs to introduce a plurality of reality, without reducing it into relativism. It would be better if adherent to the religion that gives explanation. 2). In public space, multicultural dimension needs encouragement, besides in political form, also in the expression of art, theater, music and film. 3). It is necessary to develop a program that enables the establishment of a minority refresher in politics, education and employment. 4). Governments need to encourage mass media managers such as radio, television, newspapers, magazines and the Internet to pay attention and have multicultural concerns.

Other forms of creativity are necessary to intensify the encounter and dialogue. The multicultural policy usually concern to the establishment of the majority group who have enjoyed the privilege of being a dominant group. The cause is that multiculturalism has implications for the problems of political, cultural, employment and educational representation. The first reaction would usually be to disqualify as an idea that would preserve the hegemony and their interests and supporters. The understanding that strong cultural and minority groups would be able to empower the civil society not to enter in the perspective of the opponents of multiculturalism.

The Model of education in Indonesia as well as in other countries shows the diversity of objectives that apply the strategies and means used to achieve it. Some critics have seen that the revision of the school curriculum conducted within the multicultural education program in the UK and some places in Australia and Canada, is limited to the existing cultural diversity, so it is limited to cognitive dimensions.

Adding information about cultural diversity is a model of multicultural education that includes revisions or learning materials, including revisions of textbooks. Despite the criticism of its flight in several places, the revision of such learning in the United States is considered the most important strategy in education reform and curriculum. The rewriting of American history from a more diverse perspective refers to an educational agenda championed by intellectuals, activists and educational practitioners. In Japan humanitarian activists conducted a serious advocate for revising historical books, particularly concerning the role of 
Japan in World War II in Asia. Although it has not been accepted, this business has begun to open the eyes of some communities to the importance of a new perspective on war, so that the human tragedy is not repeated. While in Indonesia it is still needed a long effort in revising textbooks to accommodate contributions and more inclusive participation for citizens of various backgrounds in the formation of Indonesia.

Another model is that multicultural education does not merely revise learning materials but reform the learning system itself. Affirmative action in the selection of students until the recruitment of teachers in America is one of the strategies to make improvements in structural inequality of minority groups. Another example is the model of "School of intermingling " Iskandar Muda in Medan that facilitates student interactions from various cultural backgrounds and composes a child program across groups. In the United States together with the inclusion of discourse multiculturalism, conducted various workshops in schools as well as in the wider community to improve social sensitivity, tolerance and reduce prejudice among groups.

To realize these models, multicul tural education in Indonesia need to use a combination of existing models, so as proposed Gorski, multicultural education can include three types of transformation, namely, self transformation, school transformation and learning process, transforming society.

The school's multicultural education implementation Model can be done by integrated in the subjects in the education Unit level curriculum. Therefore, the learning of multicultural education is expected to not alter the structure of the curriculum and not increase the allocation of time. The implementation or integration of multicultural education is clearly seen in the syllabus and RPP. Through that way, it will be implemented in learning activities both in class and outside classes contextually. In addition, multicultural education is also not a separate subject so it must be integrated and not a cognitive knowledge so that the material should be packaged in an affective form and the student's performance and the material approach can be thematically. Noteworthy in this case is the effort to implement or integrate the content of the values contained in the multicultural education into the subjects through activities so that it can be applied and reflected in the life of learners. In addition, the implementation or 
IJIERM: Vol. 2 No. 1 Januari - April 2020

integration of multicultural education must be performed and seen in the activities of all the school residents as well as in general school management. ${ }^{7}$

In a theoretical context, learning from the multicultural education models has existed and is being developed by advanced countries, known five approaches, namely, first, about cultural differences or multiculturalism. Second, education about cultural differences or cultural understanding. Third, education for cultural pluralism. Fourth, a dual-cultural education. Fifth, multicultural education as a human moral experience.

Things developed in determining the model of multiculturalism in Indonesia is the diversity of ethnic, cultural, religious, economic, social, and gender. In addition, the geographical region of Indonesia has its own uniqueness because the region and its terpencar-pencar and varied islands, which is different from the condition with other countries. With this multicultural approach, the negative phenomena that exist in the community such as discrimination, stereotypes, domination, injustices, inequality and bad prejudice can be reduced, so that the society that is equitable, harmony, immature and tolerance can be realized immediately in Indonesia.

\section{Multicultural-based of Islamic education learning models}

How is a proper multicultural-based of Islamic education learning model? It has been known to two learning models. First, the dogmatic approach, which is an approach that sees religious education in schools as the media of the teaching and religious beliefs of certain "ecclesiastical". The goal is to realize the dogmatic commitment of the students to their religion. Secondly, the social studies approach, which is an approach that sees religious outreach in school as subjects such as other subjects (social sciences) and religious material taught is seen as something secular as does the science of anthropology and sociology.

Both approaches above both contain weaknesses. The weakness of the first approach lies in its potential to foster a misplaced religious fanaticism. While the weakness of the second approach lies in the tendency of seculerisme, so it is not encouraging for the realization of good believers. Therefore, it is necessary to formulated a third approach that will be able and able to serve the needs of children's religion and in the same time also encourages harmony among the various religious believers thanks to the content of insight multiculturalism that

\footnotetext{
${ }_{7}$ Pusat Kurikulum Depdiknas, Buku Panduan Pengembangan Kurikulum, 2007. p. 25
} 
exists inherent therein. The third approach, $\mathrm{s}$ ay it, with the social planning approach (social planning approach), is an approach that encourages students understanding and commitment to the religion that he held, and at the same time also encourages the birth of the attitudes of the adherents and other religious teachings to side by hand in the diversity ${ }^{8}$.

In addition to the approaches described above, the learning strategies educators use also play an important role in shaping student attitudes and behaviors in a multicultural education context. According to Cushner, education should incorporate the following experiences, i.e. learning how and where to obtain objectives, accurate information about other cultural groups; Identify and test positive views of other cultured groups or individuals; Study tolerance to diversity through experimentation in schools and classrooms with alternative habits and practices; Face, if possible, a positive experience of first hand with different cultural groups; Develop emphatic behaviors through role playing and simulation strategies; and practice the use of a "perspective eye glass", that is, by looking at an event, a period of history, or an issue through the perspective of another cultural group. ${ }^{9}$

Ngainun Naim and Achmad Sauki (2008) Explain that in his development, the learning model using a multicultural approach must be based on the principle: First, cultural diversity is the basis for determining philosophy, theory, model, and school relationship with the local socio-cultural environment. Second, cultural diversity is the basis for the development of various learning components. Third, culture in the environment of education units is a learning resource and object of study that should be made part of the activities of Students Learning, and fourth, curriculum role as a media in developing local culture and culture.

In developing a multicultural learning model that must be blessed is a truly multicultural-laden learning activity. Learning activities are designed to provide a learning experience involving mental and physical processes through interaction between learners, learners with teachers, the environment, and other learning resources in order to achieve basic competence. The learning activities in question can be realized through the use of an inquisition learning approach and centered

${ }^{8}$ Kasinyo, Model Kurikulum pendidikan Agama Islam berbasis Multikultural, (Rajawali Perss: Jakarta, 2012), p. 45

9 Cushner K. A, Human Diversity and Education: an Integrative Approuche (New York: McGraw-Hill, 1993), p. 56. 
IJIERM: Vol. 2 No. 1 Januari - April 2020

on learners and by implementing several relevant methods such as discussion methods, questions and answers, role-playing, assignments, and so on. As for the things to be considered in developing the learning activities that contain multicultural are as follows: 1). Multicultural learning activities are structured to provide assistance to educators (teachers), in order to carry out a professional learning process. 2). Multicultural learning activities contain a series of activities that must be done by the learners. 3). Determining the sequence of learning activities must match the learning materials of multicultural content. 4). The formulation of a statement in a learning activity that is multi-loaded with a minimum of two elements, namely student activities and multicultural materials.

Once the teacher's multicultural-based learning model is expected to formulate a multi-cultural-charged competency indicator. Multi-cultural-charged indicators are fundamental competencies that are characterized by a measurable change in behavioural including attitudes, knowledge, and multicultural skills. Indicators are developed in accordance with the characteristics of students, subjects, education units, environment and regional potentials that are formulated in a measurable and/or observable operational verb. Indicators are used as a basis for crafting assessment tools.

Furthermore, a teacher is expected to be able to determine the type of assessment used with multicultural content. The achievement assessment of the multicultural-charged basic competencies for learners is done based on multicultural-charged indicators. The assessment is conducted using tests and non-test in written and oral form, performance observation, attitude measurement, assessment of the work of tasks, projects and/or products, the use of portfolios, and self-assessment. Multicultural-charged assessments are a series of activities to acquire, analyse, and interpret data on the process and outcome of student learning that are conducted systematically and continuously, making it meaningful information in decision making.

And what is not less important is that teachers are expected to be able to determine learning resources that are multi-cultural. Learning resources are references, objects and/or multicultural materials used for learning activities, which are printed and electronic media, resource-related, physical, natural, social and cultural environments. The determination of the multi-culture-laden learning resources is based on the competency and basic competencies and learning materials, learning activities, and competency achievement indicators. 


\section{Multicultural-based Islamic education learning medias}

The word media comes from the Latin language, which is a plural from a medium word that literally means ' middleman ' or' Introduction ' 10 . So the media language means an introduction to the message from the sender to the message recipient. More specifically, the introduction of media in the learning process teaching encourages to be interpreted as graphic tools, Photographics, or Electronic resources to capture, process, and reconstruct information Visual or Verbal $^{11}$

AECT (Association of Educatio $\mathrm{n}$ and Communication Technology) Give boundaries on the media as all forms and channels to be used to convey messages or information. As for the National The Education Association (NEA) defines the media as all objects can be manipulated, viewed, heard, read, or talked about by the instrument used for the activity ${ }^{12}$

Fleming mentions media with a flat term which is interpreted cause or tool that intervenes in two parties and it. With the term of media indicates the function or Its role, which is to regulate the effective relationship between the two main parties in the learning process of learners and the content of lessons. In addition, the media can also reflect the understanding that every learning system the mediation role, from the teacher to the most can be called media. The media summary is a tool delivering or delivering learning messages.

Meanwhile, according to Anderson, the learning medium is media that allows a direct relationship between the work and the a developer's subjects with the students. In general if the role of teachers using learning media is very different from the role of a teacher ' ordinary ' according to Azhar Arsyad (2003) The educational media has the following common traits: 1. Educational media has a physical understanding of today known as hardware, that is, something that can be seen, heard, or touched with the sensory. 2. Educational media has a nonphysical understanding known as software (software), which is the content of the message contained in the hardware that is the content that wants to be conveyed to learners. 3. The emphasis of educational media is on visual and audio. 4. Educational media has an understanding of tools on the learning process both inside and outside the classroom. 5. Educational Media is used in the framework

\footnotetext{
10 Arief S. Sadiman, dkk, Media Pembelajaran Babasa, Bandung: Rosyda karya, 2006), p. 6.

11 Azhar Arsyad, Media Pembelajaran Siswa Aktif, Bandung: Rosyda karya, 2003), p. 3.

${ }^{12}$ Koyo K., dkk, Introduction of Educatioanal, (Journal of Education;USA, 1985), p. 42.
} 
IJIERM: Vol. 2 No. 1 Januari - April 2020

of communication and interaction of teachers and learners in the learning process. 6. Educational Media can be used in bulk (for example: Radio, television), large groups and small groups (example: movies, video slides, OHP), or individuals (example: modules: Computers, radio, tape/cassette, video, recorder)

Based on the various opinions above, it can be concluded that the meaning of learning media is everything that can be used to transmit messages from the sender to the recipient so that it stimulates the mind, feeling, attention and interest and willingness of learners in such a way that the learning process takes place in achieving the objectives of learning effectively. The meaning of educational media as above is based on the assumption that the education/learning process is identical with a process of communication. In the process of communication there are the components involved in it, namely the source of the message, message recipients, media and feedback. The source of the message is something (the person) that delivers the message. Message is the content of the contents of the doctrine contained in the curriculum that is poured into certain symbols (encoding). The recipient of the message is a student by interpreting the symbols so that it is understood as a message (decoding). Media is an intermediary that delivers messages from the source to the message recipients.

According to Shalahuddin the basic conception of religious education is all activities that have to do with religious education material, both in the form of tools (props) techniques or methods that can effectively be used by religious teachers in order to achieve a specific goal, and not contrary to the sharia of religion itself. ${ }^{13}$

Media can also be called tools while commonly used at this time is an audiovisual aids, which means audiovisual aids are materials or tools used in the situation to help the writings and words spoken in transmitted knowledge, attitudes, and ideas. ${ }^{14}$ The tools are among others: (1) whiteboards and newsletters, (2) charts, graphs, charts, and maps, (3) dramas, Leather puppets, (4) exhibitions, (5) Flannel boards and Pasteboard, (6) images, photographs, and printed materials (models, objects, and specimen), (7) television, radio, and video tape, (8) tape recorders, (9) posters, cartoons, and clippings, (10) films, slides, filmstrips (Morgan, et al.,1976)

\footnotetext{
${ }^{13}$ Mahfudh Shalahuddin,Media Pandidikan Agama (Surabaya: Bina Ilmu, 2006), p. 10

${ }^{14}$ Suprijanto, Pendidikan Orang Dewasa Dari Teori Hingga Aplikasi, Jakarta: Bumi Aksara, 2009), p. 171
} 


\section{Multicultural-based Islamic education learning resources}

Education is generally the process of transferring cultural values from one generation to another. The difference is in terms of values that are moved (taught). In Islamic education, the values are moved derived from the sources of Islamic values as the foundation of Islamic Educatio $n$ The Foundation consists of the Qur'an and Sunnah Prophet Muhammad SAW that was developed with Ijtihad and so on. ${ }^{15}$ Thus, Islamic education is a process of guidance both physical and spiritual based on the teachings of Islam to the formation of muslim personality according to the sizes of Islam.

Education must include aspects of religious education; Moral and scientific education; Sexual education; Ethics; Physical education; Health. These aspects play a role in guiding and developing the potential of human beings, which includes: cognitive development, which is an intellectual ability that is continuously developed through Islamic education; The affective development, which is the specificity of the understanding and knowledge of reality and truth, man must undergo the process of developing feelings and passion to be broad; Psychomotor development, is a science of knowledge in the moral and charitable (shaleh).

In fact, Islamic education is the business of muslim adults who fear to realize and guide the growth and development of the students basic ability through Islamic teachings toward the maximum point of growth and development.

Islamic education directs man to a better life, namely by raising the his humanitarian degree, as a guider in earth (khalifah fi ardl), according to basic skills and teaching skills that continue to be able to be developed with human resources given by Allah SWT.

Islamic religion gives the principles of the view that the universe is the creation of Allah SWT who must be learned (tafakekur) and managed by humans through the ability of thinking and all abilities of his soul and his life on the other hand man is a creature formed from the spirit that is always nervous and need guidance to be able to feel close to the creator. Because the human being is a servant, in this case it takes the fun and the harmony of the direction and aims and where the role of Islamic blowing is needed.

\footnotetext{
15 Zakiyah Daradjat, Ilmu Pendidikan Islam (Jakarta:Bumi Aksara,2007), p. 19.
} 
IJIERM: Vol. 2 No. 1 Januari - April 2020

The Learning Resource in a multicultural-based Islamic education is developed with regard to the values of Islamic mercy to all universe (Islam rahmatan li al-alamin) who put forward the principles of Islamic humanism, tolerant, democratic, and accommodating local cultures. The principles of Islamic mercy to all universe in this curriculum are; First, Islamic humanism means to view the unity of man as a creature of God's creation, has the same origin, brings about the sense of inhumanity, and to dream the association of better life. Islamic humanism values are: prejudiced, disciplined, honest, good to fellow human beings, and are fair. Second, the Islamic tolerant means to appreciate the opinions, views, beliefs, or habits that differ from the establishment of a person, also does not compel, remain in good standing, meek, and forgive each other. The values of Islamic tolerant are: prejudiced, living in harmony, and maintaining unity. Thirdly, democratic means that prioritizes equal rights and obligations and same treatment for others by prioritizing freedom of expression, assembly, and opinion in accordance with applicable norms and laws. The values of democratic Islam include: self-control, discipline, responsibility, competing in goodness, critical thinking, and maintaining unity. And fourth, accommodating local culture means to admit, accommodating, and respect the differences and diversity of culture, which is in the community to seek and facilitate social relations, as well as mutual cooperation to achieve the common good.

\section{CONCLUSION}

In this paper the author has focused the discussion on the three formula problems mentioned in Chapter one in this chapter the author concluded the discussion in advance as an answer to the problem formulation. The conclusion is as follows: The first, is about multicultural-based Islamic religious education learning model. In developing a multicultural learning model that must be blessed is a truly multicultural-laden learning activity. Learning activities are designed to provide a learning experience involving mental and physical processes through interaction between learners, learners with teachers, the environment, and other learning resources in order to achieve basic competencies. The learning activities in question can be realized through the use of an inquisition learning approach and centered on learners and by implementing several relevant methods such as discussion methods, questions and answers, role-playing, assignments, and so on. The second, is about learning media of Islamic religious education. Media can also 
be called tools while commonly used at this time is an audiovisual aids, which means audiovisual aids are materials or tools used in the situation to help the writings and words spoken in the transmission of knowledge, attitudes, and ideas in the development of Islamic education multicultural-based. The media are: (1) whiteboards and newsletters, (2) charts, gra phs, charts, and maps, (3) dramas, leather puppets, (4) exhibitions, (5) flannel boards and pasteboard, (6) images, photographs, and printed materials (models, objects, and specimen), (7) television, radio, and video tape, (8) tape recorders, (9) posters, cartoons, and clippings, (10) films, slides, filmstrips. And the third, is about educational sources of Islamic multicultural-based learning. The sources of Islamic values as a cornerstone of Islamic education are the foundation consists of the Qur'an and hadist that was developed with Ijtihad, and so on and from the source of learning it in the Islamic education based multicultural, developed with regard to the values of Islamic mercy to all universe (Islam Rahmatan li Al-alamin), that put forward the principles of Islamic humanism, tolerant, democratic, and accommodating local cultures. 
IJIERM: Vol. 2 No. 1 Januari - April 2020

\section{Bibliograpy}

Arsyad, Azhar. Media Pembelajaran Siswa Aktif, Bandung: Rosyda karya, 2003)

Cushner, K. A, Human Diversity and Education: an Integrative Approuche (New York: McGraw-Hill, 1993)

Daradjat, Zakiyah. Ilmu Pendidikan Islam (Jakarta:Bumi Aksara,2007)

Kasinyo, Model Kurikulum pendidikan Agama Islam berbasis Multikultural, (Rajawali Perss: Jakarta, 2012)

Koppelman, Affirming diversity: The sociopolitical context of multicultural education (Boston: Pearson, 2008)

Koyo K., dkk, Introduction of Educatioanal, (Journal of Education;USA, 1985)

Mahfud, Chairul. Pendidikan Multikultural (Yogyakarta: Pustaka Pelajar, 2007)

Mahfudh, Shalahuddin. Media Pandidikan Agama (Surabaya: Bina Ilmu, 2006)

Oregon Department of Education, Multicultural Education - Definition, accesed by 19 Juni 2019, http://www.ode.state.or.us/search/page/?id=2575,

Pusat Kurikulum Depdiknas, Buku Panduan Pengembangan Kurikulum, 2007.

Rus'an dan Sri Dewi Lisnawaty, Urgensi Pendidikan Multikultural dalam Pendidikan Islam Di Madrasah Aliyah Negeri (MAN) Poso Pesisir, Istiqra, Vol. 1, No. 1 (2013)

Sadiman, Arief S. dkk,, Media Pembelajaran Bahasa, Bandung: Rosyda karya, 2006)

Supriadi, Dedi. Reformasi Pendidikan dalam Konteks Otonomi Daerah (Yogyakarta: Adicita, 2000)

Suprijanto, Pendidikan Orang Dewasa Dari Teori Hingga Aplikasi, (Jakarta: Bumi Aksara, 2009)

Sutijono, Multicultural Education in Indonesia: An Alternative for National Education in Global Era, Journal Sosio Humanika: Jurnal Pendidikan Sains Sosial dan Komunikasi. Vol. 3, No. 12010. 